Website : http://ejournal.umm.ac.id/index.php/ipa | E-mail : jpa@umm.ac.id

Jurnal Perempuan dan Anak (JPA), Vol. 1 No. 1, Februari 2021, pp. 46-57

ISSN: 2442-2614 print | 2716-3253 online

Universitas Muhammadiyah Malang

\title{
Analisis Pantang Makan Dengan Derajat Luka Perineum Terhadap Penyembuhan Luka Pada Ibu Nifas Hari Ke-7 Di PMB Ibunda Ny. Indah S.W,SST Desa Cendono Kecamatan Kandat
}

\section{An analysis on the abstinence with the degree of perineal wounds against wound healing on the 7th day postpartum mothers at PMB of Mrs. Indah S.W, SST, Cendono Village, Kandat District}

\author{
Irma Ayu Dwi Kasari ${ }^{*}$, Candra Wahyuni ${ }^{2}$ \\ a),b) IIK STRADA, J1. Manila, No. 37, Sumberece, Kec. Pesantren, Kota Kediri, Jawa Timur, Indonesia. \\ *Corresponding Author \\ e-mail : irmaayu872@gmail.com
}

\begin{abstract}
Abstrak
Persalinan merupakan peristiwa keluarnya bayi, plasenta dan selaput amnion. Dalam proses pengeluaran buah kehamilan ini sering kali mengakibatkan perlukaan jalan lahir. Luka-luka biasanya ringan, tetapi kadangkadang terjadi juga luka yang luas dan berbahaya. Robekan perineum terjadi pada hampir semиa persalinan pertama dan tidak jarang juga pada persalinan berikutnya. Oleh karena itu informasi yang sangat memadahi tentang pola makan selama kehamilan pada ibu hamil sangat diperlukan dalam mempersiapkan masa kehamilannya sampai waktu kelahiran. Karena pola makan yang baik selama kehamilan akan berdampak baik, baik bagi kesehatan ibu maupun janinnya.Penelitian ini bertujuan untuk mengetahui hubungan pola makan selama kehamilan terhadap berat badan bayi baru lahir pada ibu nifas 0 - 7 hari di Desa Cendono Kecamatan Kandat Kabupaten Kediri. Desain penelitian yang digunakan adalah Retrospektif, populasinya mengambil seluruh ibu nifas pada hari ke-7 di PMB IBUNDA Ny. Indah S.W,SST Desa Cendono Kecamatan Kandat pada bulan Maret 2019. Dengan menggunakan Purposive sampling, diperoleh 15 responden yang memenuhi kriteria inklusi. Parameter yang digunakan adalah jawaban kuisioner pantang makan selama satu minggu masa nifas, lembar observasi derajat luka perineum, dan lembar observasi penyembuhan luka perineum. Hasil penelitian menunjukkan bahwa tingkat pantang makan responden selama satu minggu masa nifas, 9 responden (60\%) melakukan pantang makan, 6 responden (40\%) melakukan tidak pantang makan. Sedangkan ibu dengan luka perineum derajat II adalah 9 responden (60\%), dan dengan luka perineum derajat III adalah 6 responden (40\%). Dan untuk penyembuhan luka ada 7 responden (46.7\%) yang lukanya sudah sembuh, dan 8 responden (53,3\%) yang luka perineumnya belum sembuh. Hasil pengumpulan data tersebut diolah dengan uji analitik korelasi dengan menggunakan uji Spearman Rank Corelation. Hasil analisa didapatkan nilai $\rho(0.000)<\alpha(0,05)$ maka ada hubungan yang signifikan antara pantang makan dan penyembuhan luka perineum pada ibu nifas hari ke-7 di PMB IBUNDA Ny. Indah S.W,SST Desa Cendono. Dan nilai $\rho(0.435)>\alpha(0,05)$ yang berarti tidak ada hubungan yang signifikan antara derajat luka perineum dan penyembuhan luka luka perineum pada ibu nifas hari ke-7 di PMB IBUNDA Ny. Indah S.W,SST Desa Cendono. Bagi responden agar selama nifas di upayakan untuk tidak pantang makan karena nutrisi yang dibutuhkan ibu nifas lebih banyak dan melakukan kunjungan nifas pada tenaga kesehatas di wilayahnya sesuai jadwal yang sudah diberikan untuk mengetahui penyembuhan luka perineum dan untuk mengetahui adanya infeksi atau tidak pada luka perineum.
\end{abstract}

Kata kunci : Pantang Makan, Derajat Luka Perineum, Penyembuhan Luka, Ibu nifas

\section{Abstract}

Childbirth is an event where the baby, placenta and amniotic membranes are released. In the process of releasing the fruit of this pregnancy, it often results in injury to the birth canal. The injuries are usually minor, but occasionally 
Website : http://ejournal.umm.ac.id/index.php/ipa | E-mail : jpa@umm.ac.id

Jurnal Perempuan dan Anak (JPA), Vol. 1 No. 1, Februari 2021, pp. 46-57

ISSN: 2442-2614 print | 2716-3253 online

Universitas Muhammadiyah Malang

extensive and dangerous injuries may occur. Perineal tears occur in nearly all first deliveries and not infrequently with subsequent deliveries. Therefore, very adequate information about diet during pregnancy in pregnant women is needed in preparing for the period of pregnancy until the time of birth. Because a good diet during pregnancy will have a good impact, both on the health of the mother and the fetus. This study aims to determine the relationship between diet during pregnancy and birth weight in postpartum mothers for 0-7 days in Cendono Village, Kandat District, Kediri Regency. The research design used was retrospective; the population took all postpartum mothers on the 7th day at PMB IBUNDA Ny. Indah S.W, SST Cendono Village, Kandat Subdistrict in March 2019. By using purposive sampling, 15 respondents who met the inclusion criteria were obtained. The parameters used were the answers to the abstinence questionnaire for one week of the puerperium, the perineal wound degree observation sheet, and the perineal wound healing observation sheet. The results showed that the level of abstinence from food of the respondents for one week of childbirth, 9 respondents (60\%) did not eat, 6 respondents (40\%) did not abstain from eating. Meanwhile, mothers with grade II perineal injury were 9 respondents (60\%), and with grade III perineal injury were 6 respondents (40\%). Moreover, for wound healing, there were 7 respondents (46.7\%) whose wounds had been healed, and 8 respondents (53.3\%) whose perineal wounds had not been healed. The results of the data collection were processed by analytic correlation test using the Spearman Rank Corelation test. The results of the analysis showed that the value of $\rho(0.000)<\alpha(0.05)$, so there is a significant relationship between abstinence from food and healing of perineal wounds in postpartum mothers on day 7 at PMB IBUNDA Ny. Indah S.W, SST Cendono Village. The value of $\rho(0.435)>\alpha(0.05)$ means that there is no significant relationship between the degree of perineal wounds and healing of perineal wounds in postpartum mothers on day 7 at PMB IBUNDA Ny. Indah S.W, SST Cendono Village. For the respondent, abstinence from eating during the postpartum efforts should not be done because more nutritions are needed by the postpartum mother; and to make postpartum visits to health workers in their area according to the schedule that has been given to determine the healing of perineal wounds and to find out whether or not there is infection in the perineal wound.

Keyword: Abstinence from Eating, Degree of Perineal Wounds, Wound Healing, Postpartum Mothers

\section{PENDAHULUAN}

Persalinan merupakan peristiwa keluarnya bayi, plasenta dan selaput amnion. Dalam proses pengeluaran buah kehamilan ini sering kali mengakibatkan perlukaan jalan lahir. Luka-luka biasanya ringan, tetapi kadang-kadang terjadi juga luka yang luas dan berbahaya. Robekan perineum terjadi pada hampir semua persalinan pertama dan tidak jarang juga pada persalinan berikutnya (Ernawati, 2010). Perlukaan pada jalan lahir dapat pula terjadi oleh karena memang disengaja seperti pada tindakan episiotomi. Tindakan untuk mencegah terjadinya robekan perineum yang luas dan dalam disertai pinggir yang tidak rata, dimana penyembuhan luka akan lambat atau terganggu. Luka insisi yang lurus ( rata ) lebih mudah diperbaiki dan lebih cepat sembuh dibanding luka laserasi yang campang-camping serta tidak terkendali(Ernawati, 2010).

Luka perineum ada yang ringan sampai berat. Robekan luka perineum dibedakan menjadi robekan derajat luka, dari robekan derajat 1 sampai robekan derajat 4. Tentu saja semakin dalam dan lebar luka perineum akan semakin menyebabkan nyeri. Bidan sebagai salah satu tenaga kesehatan yang bertugas menolong persalinan diharapkan mampu meminimalkan bahkan mencegah supaya ibu bersalin tidak mengalami luka perineum sehingga saat periode nifas, ibu tidak perlu merasakan nyeri luka perineum(Mulati, 2016).

Terdapat beberapa faktor yang mempengaruhi dalam penyembuhan luka, Faktor yang mempegaruhi penyembuhan luka perineum diantaranya yaitu, status nutrisi, istirahat, stress, infeksi, merokok, kondisi medis dan pengobatan, dan obesitas (Boyle, 2008). Faktor yang mempengaruhi proses penyembuhan luka salah satunya status nutrisi, diperlukan asupan protein, vitamin A dan C. 
Website : http://ejournal.umm.ac.id/index.php/ipa | E-mail : jpa@umm.ac.id

Jurnal Perempuan dan Anak (JPA), Vol. 1 No. 1, Februari 2021, pp. 46-57

ISSN: 2442-2614 print | 2716-3253 online

Universitas Muhammadiyah Malang

protein mensuplai asam amino, yang dibutuhkan untuk perbaikan jaringan dan degenarasi. Diet yang baik juga mempertahankan tubuh terhadap infeksi (Johnson \& Wendy, 2004)

Namun, fenomena yang sering dijumpai di masyarakat adalah adanya pembatasan makanan pada ibu nifas. Ibu nifas dilarang mengonsumsi beberapa pangan selama selang waktu tertentu. Misalnya, ibu yang baru melahirkan pada Suku Dayak dipantang untuk tidak makan daging, telur, ikan, sayuran seperti labu air, timun, dan sayuran berbumbu7. Budaya pantang makan tersebut berkaitan dengan tidak sembuhnya luka perineum pada ibu nifas(Rahmawati and Triatmaja, N, 2015).

AKI Provinsi Jawa Timur tahun pada tahun 2010 sebesar 104,97 per 100.000 kelahiran hidup dan mengalami peningkatan pada tahun 2011 sebesar 116,01 per 100.000 kelahiran hidup. Kasus kematian ibu di Jawa Timur tahun 2010 dapat terjadi karena komplikasi pada masa kehamilan, persalinan dan nifas, masalah gizi merupakan salah satu penyebab kematian maternal. Komplikasi yang sering terjadi pada masa nifas adalah perdarahan 17\%, infeksi 14\%, eklamsi 37\% dan lain - lain 32\%. Masalah infeksi pada masa nifas tersebut 25-55\% disebabkan oleh infeksi jalan lahir. Infeksi ini terjadi karena masih banyaknya ibu-ibu yang tidak makan-makanan yang bergizi, 2 kasus tertinggi masalah gizi pada masa nifas antara lain anemia gizi besi $24,02 \%$, kurang energi kronik 13,91\%(Rumah et al., 2019).

Data dari PMB Ibunda menyatakan bahwa jumlah ibu bersalin tahun 2017 sebanyak 69 persalinan fisiologi dan 50 diantaranya mengalami luka perineum. Jumlah ibu bersalin tahun 2018 sebanyak 72 persalinan fisiologi dan 53 mengalami luka perineum. Jumlah ibu bersalin tahun 2019 sebanyak 85 persalinan fisiologi dan 78 mengalami luka perineum. Berdasarkan data tersebut dapat dilihat bahwa terjadi peningkatan jumlah ibu bersalin yang mengalami ruptur perineum (PMB Ibunda, 2019).

Hasil wawancara awal terhadap $10 \mathrm{ibu}$ yang pernah mengalami ruptur perineum di BPM Ibunda terdapat $4 \mathrm{ibu}$ yang mengalami penyembuhan luka perineum lebih cepat dan memiliki gizi baik, 6 ibu yang mengalami penyembuhan luka perineum lebih lambat karena ibu memiliki pola makan tarak dan status gizinya dalam kategori kurang.

Setiap luka tentunya berisiko mengalami infeksi, apalagi jika status gizi atau nutrisi ibu kurang baik. Malnutrisi secara umum dapat mengakibatkan berkurangnya kekuatan luka, meningkatnya dehisensi luka, meningkatnya kerentanan terhadap infeksi dan parut dengan kualitas yang buruk (Taylor, 2015). Masa post partum ini sangat diperlukan nutrisi yang bermutu tinggi dengan cukup kalori, protein, serta vitamin. Faktor nutrisi ini akan memengaruhi proses penyembuhan luka pada perenium, vulva hygine, luas luka, umur, dan vaskularisasi. Jika kebutuhan makanan ibu nifas terpenuhi dengan makan makanan yang bergizi seimbang, maka ibu post partum akan sehat dan segar. Pada ibu post partum yang memiliki budaya berpantang makanan seperti makan telur, ayam, ikan, daging akan memengaruhi asupan gizi ibu post partum tersebut sehingga dapat memperlambat proses penyembuhan luka pada perenium(Susanti, Kebidanan and Sukorejo, 2015).

Nutrisi atau gizi adalah zat yang di butuhkan oleh tubuh untuk keperluan metabolisme. Pada ibu nifas gizi yang banyak di perlukan adalah kalori dan protein untuk proses penyembuhan luka 
Website : http://ejournal.umm.ac.id/index.php/ipa | E-mail : jpa@umm.ac.id

Jurnal Perempuan dan Anak (JPA), Vol. 1 No. 1, Februari 2021, pp. 46-57

ISSN: 2442-2614 print | 2716-3253 online

Universitas Muhammadiyah Malang

perineum. Seorang ibu nifas harus makan nasi dan lauknya lebih banyak dari waktu sebelum melahirkan dan makan makanan yang beraneka ragam(Jalan, 2013).

\section{METODE PENELITIAN}

Desain penelitian yang digunakan adalah Retrospektif, populasinya mengambil seluruh ibu nifas pada hari ke- 7 di PMB IBUNDA Ny. Indah S.W,SST Desa Cendono pada bulan Maret 2020. Dengan menggunakan Purposive sampling, diperoleh 15 responden yang memenuhi kriteria inklusi. Parameter yang digunakan adalah jawaban kuisioner pantang makan selama 7 hari masa nifas, lembar observasi derajat luka perineum, dan lembar observasi penyembuhan luka .

\section{HASIL DAN PEMBAHASAN}

Tabel 1 Distribusi responden menurut usia

\begin{tabular}{|c|c|c|c|}
\hline $\begin{array}{l}\mathrm{N} \\
\mathrm{O}\end{array}$ & $\begin{array}{c}\text { Kelompok } \\
\text { Usia }\end{array}$ & Frekuensi & $\begin{array}{c}\text { Prosentase } \\
(\%)\end{array}$ \\
\hline 1. & $15-20$ & 2 & 13.3 \\
\hline 2. & tahun & 7 & 46.7 \\
\hline 3. & $21-25$ & 4 & 26.7 \\
\hline \multirow[t]{5}{*}{4.} & tahun & 2 & 13.3 \\
\hline & $26-30$ & & \\
\hline & tahun & & \\
\hline & $>30$ tahun & & \\
\hline & Jumlah & 15 & 100 \\
\hline
\end{tabular}

Dari tabel 1 diatas menunjukkan bahwa dari 15 responden hampir setengahnya berusia antara 20 25 tahun yaitu 6 responden $(40 \%)$.

Tabel 2 Distribusi responden menurut Status Pendidikan

\begin{tabular}{lccc}
\hline No & Pendidikan & Frekuensi & $\begin{array}{c}\text { Prosentase } \\
(\%)\end{array}$ \\
\hline 1. & SD & 2 & 13.3 \\
2. & SMP & 6 & 40 \\
3. & SMA & 6 & 40 \\
4. & Perguruan & 1 & 6.7 \\
& Tinggi & & \\
\hline & Jumlah & 15 & 100 \\
\hline
\end{tabular}

Dari tabel 2 dapat dilihat bahwa status pendidikan responden rata-rata berada pada level pendidikan dasar (SMP dan SMA) yaitu $40 \%$ dan $40 \%$ berpendidikan menegah, hanya $6.7 \%$ yang berpendidikan tinggi.

Tabel 3 Distribusi responden menurut Status Pekerjaan

No Pekerjaan Frekuensi Prosentase

$(\%)$ 
Website : http://ejournal.umm.ac.id/index.php/ipa | E-mail : jpa@umm.ac.id

Jurnal Perempuan dan Anak (JPA), Vol. 1 No. 1, Februari 2021, pp. 46-57

ISSN: 2442-2614 print |2716-3253 online

Universitas Muhammadiyah Malang

\begin{tabular}{lccc}
\hline 1. & Swasta & 2 & 13.3 \\
2. & Wiraswasta & 2 & 13.3 \\
3. & PNS/TNI/POLRI & 2 & 13.3 \\
4. & Ibu Rumah & 9 & 60 \\
& Tangga (IRT) & & \\
\hline & Jumlah & 15 & 100 \\
\hline
\end{tabular}

Dari tabel 3 Status pekerjaan mayoritas responden adalah ibu rumah tangga (IRT) yaitu 9 dari 15 (60\%), kemudian 2 responden (13.3\%) sebagai swasta, selanjutnya 2 responden (13.3\%) sebagai wiraswasta dan yang bekerja sebagai pegawai negeri sipil yaitu 2 orang $(13.3 \%)$.

Tabel 4 Distribusi responden menurut Status Penyakit yang pernah diderita

\begin{tabular}{cccc}
\hline No & $\begin{array}{c}\text { Penyakit yang } \\
\text { Pernah } \\
\text { diderita }\end{array}$ & Frekuensi & $\begin{array}{c}\text { Prosentase } \\
(\%)\end{array}$ \\
\hline 1 & DM & 0 & 0 \\
2 & Hipertensi & 0 & 0 \\
3 & Tidak ada & 15 & 100 \\
\hline & Jumlah & 15 & 100 \\
\hline
\end{tabular}

Dari tabel 4 dapat dilihat bahwa dari 15 responden seluruhnya (100\%) tidak ada penyakit yang pernah diderita.

Tabel 5 Distribusi responden menurut Status Penyakit sekarang

\begin{tabular}{cccc}
\hline No & $\begin{array}{c}\text { Riwayat penyakit } \\
\text { Sekarang }\end{array}$ & Frekuensi & $\begin{array}{c}\text { Prosentase } \\
(\%)\end{array}$ \\
\hline 1 & DM & 0 & 0 \\
2 & Hipertensi & 0 & 0 \\
3 & Tidak ada & 15 & 100 \\
\hline & Jumlah & 15 & 100 \\
\hline
\end{tabular}

Dari tabel 5 dapat dilihat bahwa dari 15 responden seluruhnya (100\%) tidak ada yang memiliki penyakit yang diderita saat ini.

Tabel 6 Distribusi responden menurut Status Penyakit keturunan

\begin{tabular}{cccc}
\hline No & $\begin{array}{c}\text { Riwayat penyakit } \\
\text { Keturunan }\end{array}$ & Frekuensi & $\begin{array}{c}\text { Prosentase } \\
(\%)\end{array}$ \\
\hline 1 & DM & 0 & 0 \\
2 & Hipertensi & 0 & 0 \\
3 & Tidak ada & 15 & 100 \\
\hline & Jumlah & 15 & 100 \\
\hline
\end{tabular}

Dari tabel 6 dapat dilihat bahwa dari 15 responden seluruhnya (100\%) tidak ada yang mempunyaki penyakit keturunan. 
Tabel 7 Distribusi responden menurut Status ketaatan minum obat

\begin{tabular}{cccc}
\hline No & $\begin{array}{c}\text { Ketaatan } \\
\text { Konsumsi obat }\end{array}$ & Frekuensi & $\begin{array}{c}\text { Prosentase } \\
(\%)\end{array}$ \\
\hline 1 & Teratur & 11 & 73.3 \\
2 & Tidak teratur & 4 & 26.7 \\
\hline & Jumlah & 15 & 100 \\
\hline
\end{tabular}

Dari tabel 7 dapat dilihat bahwa dari 15 responden sebagian besar responden (73.3\%) taat dalam mengkonsumsi obat, dan hampir setengahnya yaitu 4 responden (26.7\%) tidak minum obat secara teratur.

\begin{tabular}{|c|c|c|c|}
\hline No & $\begin{array}{l}\text { Cara personal } \\
\text { hygiene }\end{array}$ & Frekuensi & $\begin{array}{c}\text { Prosentase } \\
(\%)\end{array}$ \\
\hline 1. & Hanya dibersihkan & 4 & 26.7 \\
\hline 2. & menggunakan tisu & 6 & 40 \\
\hline 3. & $\begin{array}{l}\text { Hanya di } \\
\text { bersihkan dengan }\end{array}$ & 5 & 33.3 \\
\hline \multirow[t]{3}{*}{4.} & air & & \\
\hline & $\begin{array}{l}\text { Dibersihkan } \\
\text { dengan air dan } \\
\text { sabun }\end{array}$ & & \\
\hline & Jumlah & 15 & 100 \\
\hline
\end{tabular}

Dari tabel 8 dapat dilihat bahwa dari 15 responden, hampir setengahnya atau 4 responden $(26.7 \%)$ cara personal hygiene hanya dibersihkan dengan tisu, hampir setengahnya atau 6 responden (40\%) cara personal hygiene hanya dibersihkan dengan air, hampir setengahnya atau 5 responden (33.3\%) cara personal hygiene dibersihkan dengan air dan sabun.

Tabel 9 Distribusi responden menurut Status Pantang makan

\begin{tabular}{clcc}
\hline No & $\begin{array}{l}\text { Pantang } \\
\text { Makan }\end{array}$ & Frekuensi & $\begin{array}{c}\text { Prosentas } \\
\mathrm{e}(\%)\end{array}$ \\
\hline 1. & $\begin{array}{l}\text { Pantang } \\
\text { makan }\end{array}$ & 9 & 60 \\
2. & $\begin{array}{l}\text { Tidak } \\
\text { pantang } \\
\text { makan }\end{array}$ & 6 & 40 \\
\hline & Jumlah & 15 & 100
\end{tabular}

Dari tabel 9 dapat dilihat bahwa dari 15 responden, hampir seluruhnya responden melakukan pantang makan yaitu 9 responden $(60 \%)$, dan hampir setengahnya tidak pantang makan yaitu 6 responden $(40 \%)$.

Tabel 10 Distribusi responden menurut Status Derajat Luka Perineum 
Website : http://ejournal.umm.ac.id/index.php/ipa | E-mail : jpa@umm.ac.id

Jurnal Perempuan dan Anak (JPA), Vol. 1 No. 1, Februari 2021, pp. 46-57

ISSN: 2442-2614 print | 2716-3253 online

Universitas Muhammadiyah Malang

\begin{tabular}{cccc}
\hline No & $\begin{array}{c}\text { Derajat } \\
\text { Luka } \\
\text { Perineum }\end{array}$ & Frekuensi & Prosentase (\%) \\
\hline 1. & Derajat I & 0 & 0 \\
2. & Derajat II & 9 & 60 \\
3. & Derajat III & 6 & 40 \\
4. & Derajat IV & 0 & 0 \\
\hline & Jumlah & 15 & 100 \\
\hline
\end{tabular}

Dari tabel 10 dapat dilihat bahwa dari 15 responden, hampir seluruhnya responden mengalami luka perineum derajat II yaitu 9 responden $(60 \%)$, dan hampir setengahnya mengalami luka perineum derajat III yaitu 6 responden $(40 \%)$.

Tabel 11 Distribusi responden menurut Keadaan Luka Perineum

\begin{tabular}{cccc}
\hline No & $\begin{array}{c}\text { Keadaan Luka } \\
\text { Perineum }\end{array}$ & Frekuensi & $\begin{array}{c}\text { Prosentase } \\
(\%)\end{array}$ \\
\hline 1. & $\begin{array}{c}\text { Luka sudah } \\
\text { kering }\end{array}$ & 7 & 46.7 \\
2. & $\begin{array}{c}\text { Luka belum } \\
\text { kering }\end{array}$ & 8 & 53.3 \\
\hline & Jumlah & 15 & 100 \\
\hline
\end{tabular}

Dari tabel 11 dapat dilihat bahwa dari 15 responden, hampir setengahnya keadaan luka perineum sudah kering yaitu 7 responden (46.7\%), dan sebagian besar luka perineum belum kering yaitu 8 responden $(53.3 \%)$.

\section{Tabel 12 Hubungan Pantang MakanTerhadap Penyembuhan Luka Pada Ibu Nifas Hari Ke-7 di PMB IBUNDA Ny. Indah Desa Cendono}

\begin{tabular}{|c|c|c|c|c|c|c|}
\hline \multirow{2}{*}{$\begin{array}{c}\text { Pantang } \\
\text { Makan }\end{array}$} & \multicolumn{4}{|c|}{ Penyembuhan Luka } & \multirow{2}{*}{\multicolumn{2}{|c|}{ Total }} \\
\hline & $\begin{array}{l}\text { Luka } \\
\text { sudah } \\
\text { kering }\end{array}$ & $\%$ & $\begin{array}{l}\text { Luka } \\
\text { belum } \\
\text { kering }\end{array}$ & $\%$ & & \\
\hline $\begin{array}{l}\text { Tidak } \\
\text { Pantang }\end{array}$ & 6 & 40 & 0 & 0 & 6 & 40 \\
\hline Pantang & 1 & 6.7 & 8 & $\begin{array}{c}53 . \\
3\end{array}$ & 9 & 60 \\
\hline Total & 7 & $\begin{array}{c}46 . \\
7\end{array}$ & 10 & $\begin{array}{c}53 . \\
3\end{array}$ & 15 & 100 \\
\hline
\end{tabular}

Dari tabel 12. dapat dilihat bahwa dari 15 responden, hampir setengahnya responden melakukan tidak pantang makan yaitu 6 responden (40\%) dan seluruhnya 6 responden (40\%) lukanya sudah kering, sedangkan sebagian besar dari 15 responden melakukan pantang makan yaitu 9 responden (60\%) dan hampir seseluruhnya 8 responden $(53.3 \%)$ luka perineumnya belum kering. 
Tabel 13 Hubungan Derajat Luka Terhadap Penyembuhan Luka Pada Ibu Nifas Hari Ke-7 di PMB IBUNDA Ny. Indah Desa Cendono

\begin{tabular}{ccccccc}
\hline $\begin{array}{c}\text { Deraja } \\
\text { t Luka }\end{array}$ & \multicolumn{3}{c}{ Penyembuha Luka } & Total & \% \\
\cline { 2 - 5 } & $\begin{array}{c}\text { Luka } \\
\text { sudah } \\
\text { kering }\end{array}$ & $\%$ & $\begin{array}{c}\text { Luka } \\
\text { belum } \\
\text { kering }\end{array}$ & $\%$ & & \\
\hline $\begin{array}{c}\text { Deraja } \\
\text { t I }\end{array}$ & 0 & 0 & 0 & 0 & 0 & 0 \\
\hline $\begin{array}{c}\text { Deraja } \\
\text { t II }\end{array}$ & 5 & 33.3 & 4 & 26.7 & 9 & 60 \\
\hline $\begin{array}{c}\text { Deraja } \\
\text { t III }\end{array}$ & 2 & 13.3 & 4 & 26.7 & 6 & 40 \\
\hline $\begin{array}{c}\text { Deraja } \\
\text { t IV }\end{array}$ & 0 & 0 & 0 & 0 & 0 & 0 \\
\hline Total & $\mathbf{7}$ & $\mathbf{4 6 . 6}$ & $\mathbf{8}$ & $\mathbf{5 3 . 4}$ & $\mathbf{1 5}$ & $\mathbf{1 0 0}$ \\
\hline
\end{tabular}

Dari tabel 13. dapat dilihat bahwa dari 15 responden, sebagian besar responden mengalami luka perineum derajat II yaitu 9 responden (60\%) dan hampir setengahnya 5 responden(33.3\%) lukanya sudah kering, sedangkan hampir setengahnya dari 15 responden mengalami luka perineum derajat III yaitu 6 responden (40\%) dan hampir setengahnya 4 responden $(26.7 \%)$ luka perineumnya belum kering.

\subsection{Hasil Uji Statik}

Tabel 15 Hasil Uji Statistik Pantang Makan Dan Derajat Luka Perineum Terhadap Penyembuhan Luka Pada Ibu Nifas Hari Ke-7 di PMB IBUNDA Ny. Indah Desa Cendono. 
Website : http://ejournal.umm.ac.id/index.php/ipa | E-mail : jpa@umm.ac.id

Jurnal Perempuan dan Anak (JPA), Vol. 1 No. 1, Februari 2021, pp. 46-57

ISSN: 2442-2614 print | 2716-3253 online

Universitas Muhammadiyah Malang

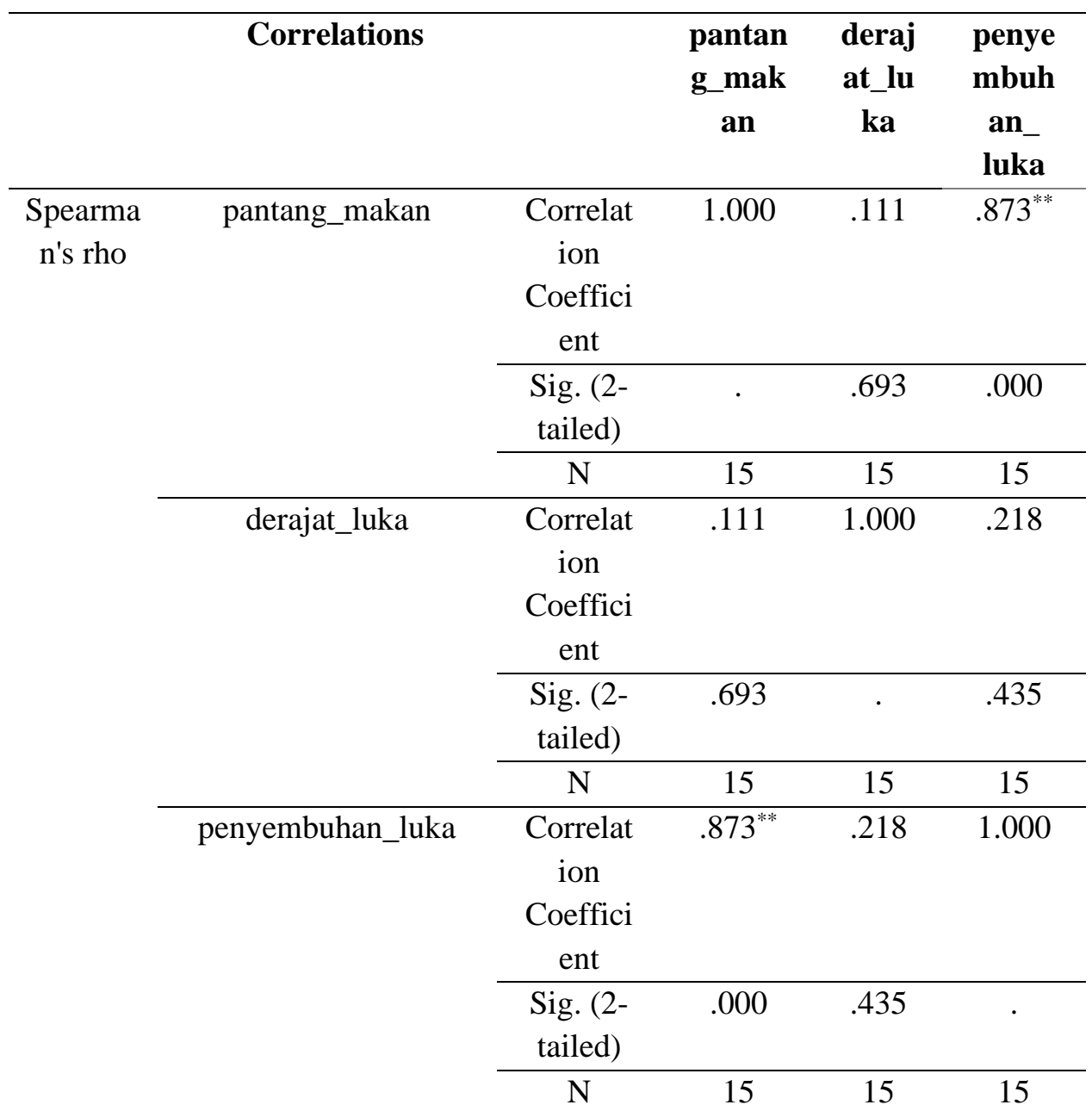

Berdasarkan tabel di atas dapat diketahui bahwa koefisien korelasi antara pantang makan terhadap penyembuhan luka adalah 0,873 ". Nilai $r=0,873$ " berarti antara pantang makan selama masa nifas 7 hari terhadap penyembuhan luka sangat berhubungan berada dalam kategori sangat kuat. Sedangkan untuk hasil uji statistik diketahui bahwa didapatkan tingkat signifikansi 0,000 $<0,05$ yang berarti H1 diterima, sehingga dapat disimpulkan bahwa ada hubungan Pantang Makan Terhadap penyembuhan luka di PMB IBUNDA Ny. Indah Desa Cendono. Dan berdasarkan tabel tersebut dapat di ketahui bahwa koefisien korelasi antara derajat luka perineum terhadap penyembuhan luka adalah 0,218 ". Berarti antara derajat luka perineum terhadap penyembuhan luka adalah rendah. Untuk hasil uji statistik diketahui bahwa tingkat signifikan 0,435 > 0,05, yang berati H1 ditolak, sehingga dapat disimpulkan bahwa tidak ada hubungan antara derajat luka perineum terhadap penyembuhan luka. Jadi pantang makan dan derajat luka perineum terhadap penyembuhan luka pada ibu nifas ibu selama kehamilan yang semakin baik maka berat badan bayi yang dilahirkan semakin baik yaitu dalam kategori normal.

\subsection{Pantang Makan Terhadap Penyembuhan Luka Pada Ibu Nifas Hari Ke-7 di PMB IBUNDA Ny. Indah Desa Cendono}


Website : http://ejournal.umm.ac.id/index.php/ipa | E-mail : jpa@umm.ac.id

Jurnal Perempuan dan Anak (JPA), Vol. 1 No. 1, Februari 2021, pp. 46-57

ISSN: 2442-2614 print | 2716-3253 online

Universitas Muhammadiyah Malang

Berdasarkan Analisa Hasil Penelitian tentang Pantang Makan Terhadap Penyembuhan Luka Pada Ibu Nifas Hari Ke-7 menunjukkan bahwa dari 15 responden di PMB IBUNDA Ny. Indah S. W, SST Desa Cendono pada bulan Maret 2020 di dapatkan hasil bahwa sebagian besar yang berstatus pantang makan yaitu 9 responden $(60 \%)$, dan hampir setengahnya tidak pantang makan yaitu 6 responden (40\%). 8 dari 15 responden mengalami luka perineum belum kering yang penyebabnya adalah pantang makan.

Penelitian yang dilakukan (Endah, 2016) bahwa terdapat hubungan antara konsumsi makanan protein hewani dengan penyembuhan luka pada ibu nifas. Protein hewani merupakan nutrien yang sangat berpengaruh terhadap penyembuhan luka perineum, karena protein sangat diperlukan untuk penggantian jaringan. Ibu nifas diharapkan lebih banyak mengkonsumsi protein hewani sehingga penyembuhan luka perineum akan semakin cepat(Muniroh, 2016).

Hal tersebut sesuai dengan hasil penelitian ini, yaitu terdapat hubungan pantang makan dan pemulihan luka perineum. Sebagian besar responden yang terpenuhi kebutuhan gizinya mempunyai luka perineum yang sembuh, dan sebaliknya. Hasil penelitian ini sesuai dengan penelitian di PMB IBUNDA Ny. Indah S. W, SST Desa Cendono yang menunjukkan ibu nifas dengan luka episiotomi yang segera pulih mempunyai tingkat kecukupan protein yang berarti tidak pantang makan. Makanan yang bergizi dan sesuai porsi menyebabkan ibu dalam keadaan sehat dan akan mempercepat penyembuhan luka perineum. Pantang makan mempengaruhi kecepatan penyembuhan luka.

\subsection{Derajat Luka Perineum Terhadap Penyembuhan Luka Pada Ibu Nifas Hari Ke-7 di PMB IBUNDA Ny. Indah Desa Cendono}

Berdasarkan Analisa Hasil Penelitian tentang Derajat Luka Perineum Terhadap Penyembuhan Luka Pada Ibu Nifas Hari Ke-7 menunjukkan bahwa dari 15 responden di PMB IBUNDA Ny. Indah S. W, SST Desa Cendono pada bulan Maret 2020 di dapatkan hasil bahwa sebagian besar yang berstatus derajat II luka perineum yaitu 9 responden $(60 \%)$, dan hampir setengahnya tidak berstatus derajat II luka perineum yaitu 6 responden $(40 \%)$.

Perlukaan pada jalan lahir terjadi karena memang disengaja yaitu dengan tindakan episiotomi yaitu tindakan untuk mencegah terjadinya robekan perineum yang luas dan dalam disertai pinggir yang tidak rata, dimana penyembuhan luka akan lambat atau terganggu. Luka insisi yang lurus (rata) lebih mudah diperbaiki dan lebih cepat sembuh dibanding luka laserasi atau robek spontan. Luka lebar / besar serta dalam biasanya sembuh lebih lambat daripada luka kecil(Ernawati, 2010).

Tidak terdapat hubungan derajat luka perineum terhadap pemulihan luka perineum. Sebagian besar responden mengalami luka perineum derajat II lukanya sudah kering, sedangkan hampir setengahnya luka perineum derajat III 4 luka perineumnya belum kering.

\subsection{Penyembuhan Luka Pada Ibu Nifas Hari Ke-7 di PMB IBUNDA Ny. Indah Desa Cendono}

Berdasarkan Analisa Hasil Penelitian tentang Penyembuhan Luka Pada Ibu Nifas Hari Ke-7 menunjukkan bahwa dari 15 responden di PMB IBUNDA Ny. Indah S. W, SST Desa Cendono pada bulan Maret 2020 di dapatkan hasil bahwa hampir setengahnya keadaan luka perineum sudah kering yaitu 7 responden (46.7\%), dan sebagian besar luka perineum belum kering yaitu 8 responden $(53.3 \%)$.

Jahitan luka yang kurang baik atau tidak dapat menempel pada proses epitelisasi penyembuhan luka merupakan salah indikasi terhambatnya penyembuhan luka perineum dan luka lainnya. Infeksi luka jahitan dan perawatan yang tidak bersih atau tidak steril pada luka jahitan robekan (episiotomi) daerah perineum akan mengakibatkan peradangan atau infeksi(Ernawati, 2010).

Tanda-tanda peradangan tersebut, antara lain pembengkakan kulit daerah sekitarnya merah, rasa panas dan nyeri, serta mengandung cairan nanah, tanpa atau disertai demam. Luka terinfeksi sembuh lebih 
sulit dan lebih lama. Penyembuhan luka perineum dapat terjadi perprimam atau persecundam (lambat). Yaitu jika luka-luka pada jalan lahir bila tidak disertai infeksi akan sembuh dalam $6-7$ hari. Penyembuhan luka lambat yaitu jika luka-luka pada jalan lahir sembuh dalam waktu lebih dari 6-7 hari dan bila disertai infeksi(Ernawati, 2010).

Keterbatasan penelitian ini adalah peneliti hanya menganalisis hubungan pantang makan dan derajat luka perineum terhadap penyembuhan luka perineum. Penyembuhan luka perineum tidak hanya berhubungan dengan makanan. Faktor lain yang dominan mempengaruhi penyembuhan luka perineum adalah pengetahuan ibu terkait perawatan luka.

\section{KESIMPULAN}

a. Tingkat pantang makan pada ibu nifas di PMB IBUNDA Ny. Indah S.W,SST Desa Cendono adalah dari 15 responden, responden yang mempunyai pantang makan sebanyak 9 responden $(60 \%)$, dan ibu yang tidak pantang makan sebanyak 4 responden (40\%).

b. Derajat luka perineum pada ibu melahirkan sebanyak 9 responden(60\%) pada derajat 2 luka perineum, dan sebanyak 6 responden $(40 \%)$ pada derajat 3 luka perineum.

c. Penyembuhan luka pada ibu nifas hari ke-7 di PMB IBUNDA Ny. Indah S.W, SST terdapat 7 responden $(46.7 \%)$ yang lukanya sudah sembuh, dan sebanyak 8 responden (53.3\%)yang lukanya belum sembuh.

d. Hasil analisa didapatkan nilai $\rho(0.000)<\alpha(0,05)$ antara pantang makan dan penyembuhan luka perineum maka $\mathrm{H} 1$ diterima yang berarti ada hubungan yang signifikan antara pantang makan dan penyembuhan luka perineum pada ibu nifas hari ke-7 di PMB IBUNDA Ny. Indah S.W,SST Desa Cendono. Dan nilai $\rho(0.435)>\alpha(0,05)$ antara derajat luka perineum dan penyembuhan luka maka HI ditolak yang berarti tidak ada hubungan yang signifikan antara derajat luka perineum dan penyembuhan luka luka perineum pada ibu nifas hari ke-7 di PMB IBUNDA Ny. Indah S.W,SST Desa Cendono.

\subsection{Saran}

\section{a. Bagi Responden}

Bagi responden agar selama nifas di upayakan untuk tidak pantang makan dan melakukan kunjungan nifas pada tenaga kesehatas di wilayahnya sesuai jadwal yang sudah diberikan untuk mengetahui penyembuhan luka perineum dan untuk mengetahui adanya infeksi atau tidak pada luka perineum.

b. Bagi Tempat Penelitian

Untuk meningkatkan pengetahuan ibu tentang pola makan selama kehamilan,pemerintah desa dapat berkolaborasi dengan tenaga kesehatan setempat untuk rutin mengadakan penyuluhan tentang gizi ibu nifas. Serta memperbanyak sarana informasi pada ibu nifas.

\section{c. Bagi Tenaga Kesehatan}

Tenaga kesehatan yang ada di desa perlu di harapkan secara rutin memberikan penyuluhan tentang gizi pada ibu nifas pada saat kunjungan nifas maupun saat posyandu di masing masing dusun.

d. Bagi Peneliti Selanjutnya

Penelitian selanjutnya diharapkan dapat menganalisis faktor - faktor penyembuhan yang paling dominan 
Website : http://ejournal.umm.ac.id/index.php/ipa | E-mail : jpa@umm.ac.id

Jurnal Perempuan dan Anak (JPA), Vol. 1 No. 1, Februari 2021, pp. 46-57

ISSN: 2442-2614 print |2716-3253 online

Universitas Muhammadiyah Malang

\section{DAFTAR PUSTAKA}

Ernawati, S. R. (2010) 'Faktor-Faktor Yang Berpengaruh Pada Penyembuhan Luka Perineum Ibu Pasca Persalinan Di Puskesmas Brangsong Dan Kaliwungu Kabupaten Kendal', Http//Jurnal.Unimus.Ac.Id, pp. 1-8.

Jalan, P. R. (2013) 'Jurnal Ilmiah Rekam Medis dan Informatika Kesehatan 12', 3(2), pp. 12-24.

Mulati, T. S. (2016) 'Bentuk Dan Derajat Luka Perineum Ibu Nifas Di Wilayah Kabupaten Klaten', Jurnal Kebidanan dan Kesehatan Tradisional, 1(2), pp. 110-113. doi:

10.37341/jkkt.v1i2.83.

Muniroh, S. (2016) 'Hubungan Pola Makan Dengan Proses Penyembuhan Luka Episiotomi'.

Rahmawati, E. and Triatmaja, N, T. (2015) 'Hubungan Pemenuhan Gizi Ibu Nifas Dengan Pemulihan Luka Perineum', Jurnal Wiyata, pp. 19-24. Available at: https://ojs.iik.ac.id/index.php/wiyata/article/download/30/30.

Rumah, D. I. et al. (2019) 'Peningkatan Pengetahuan Tentang Nutrisi Ibu Nifas Menggunakan Media Aplikasi "Sinnia ", 2(1).

Susanti, N. Y., Kebidanan, A. and Sukorejo, I. (2015) 'Luka Perineum Pada Ibu Post Partum Abstinence Food Effect Against Healing Perineal Wound for Post Partum Mother’, II(2), pp. 8893. 